\title{
Making Retention Pond as an Attractive Element for Site Planning at Lowland Housing Area
}

\author{
Widya Fransiska F Anwar", Fuji Amalia ${ }^{\#}$ \\ ${ }^{\#}$ Architecture Department, Faculty of Engineering, Universitas Sriwijaya, Jl.Srijaya Negara Palembang 30139, Indonesia \\ E-mail:widyafransiska@ft.unsri.ac.id,vhu_jie@yahoo.com
}

\begin{abstract}
The increasing number of the population has made the reclamation of the lowland for the site as the easiest way for a developer to fulfill the market demand. The covering area has minimized the role of lowland as water catchment area in the city. Therefore, the drainage system, as well as the availability of retention pond, must be provided in the design of site plan. The paper is aimed to investigate the use of retention pond as attracting attributes of housing product. To achieve this aim, the paper investigated how people perceive the significance of the availability of retention pond in their living environment through three variables; the function, the size and the street furniture provided. A number of 369 respondents had participated in the survey. The data from questionnaires were analyzed using descriptive statistic and factor analysis. The result shows that the availability of retention pond is not the main attractive attribute of housing product. The statistic results were complemented by the interview with the residents. The result from transcript analysis confirms the statistic results. The drainage system is considered as important one while the open area is needed for residents' social activity. The paper concludes that in designing site plan at retention pond area, the street furniture with safety standards must become first consideration before providing other landscape furniture. Hence, the retention area can be utilized as water catchment area as well as a place for supporting the residents' social activity.
\end{abstract}

Keywords - retention pond; site plan design; lowland development

\section{INTRODUCTION}

For a city that is dominated by water covered area, lowland development becomes a solution to provide a place for people activity and living place. Population and development lead to the change of land use at lowland area as well as the watershed area. The lowland area was reclaimed for housing development. It caused fragmentation, declined the capacity of lowland as water catchment area and disrupted the hydrological system of watersheds [1], [2]. The increasing number of population creates the housing demand, particularly landed house. The demand leads to the increasing of lowland occupancy for housing. The lowland conservation is neglected. In the long term, the increasing volume and extension of fragmented lowland for housing have increased the extension of the flood area.

One of the causes of flooding in the rainy season is the runoff water which cannot be accommodated by water bodies such as river or drainage system. The wider built area leads to the narrower unbuilt lowland area. By having this, the hydrology function at lowland is damaged. The maximum water retention capacity in heavy rain is decreased. These conditions cause the recharge to groundwater become smaller while the flood peak discharge becomes greater [3].
To control the development at reclaimed lowland area can be done from engineering and social aspects. From engineering aspect, the concept of blue infrastructure manages the flowing water by retention/detention pond, bioswales, low-lying lakes, infiltration parks, porous concrete, and stormwater boulevard. These technologies manage the water surplus to flow to the water container such as pond, swales, lakes, and ground. From social aspect, the green infrastructure concept complements the technical aspect not only by the greenery as water catchment area but also the social benefits to the communities by providing a healthy and beautiful environment [4], [5] Study on the resident preferences found that the free flood area is preferable than the image of the residential area. Therefore, water treatment management including drainage system and runoff water flow became the main preference that implies resident's satisfaction in housing on reclaimed lowland [6].

This paper is aimed to study the design criteria of a retention pond that not only fulfill the technical function as flood controller at housing site but also correspond the resident's preference. In order to achieve this aim, the paper investigated the user's preference for the use of surrounding area of a retention pond in relation to residents activities. 


\section{A. Technical Aspect of Retention Pond}

The retention pond manages and controls the water runoff before it flows into the river. In the context of Indonesia, the pond can be located near the river body (next or inside the water body) or have a distance from river body [7]. For reclaimed lowland area, the retention pond usually has a distance from the water body. It is a temporary container for maximum water discharge caused by heavy rain before the water charge back to normal and flows to city sewage system [7]. Besides its technical function, the retention pond also has a function for water conservation. Related to the residents, the biodiversity and greenery at retention pond is also a communal place that supports people healthy and leisure environment [3], [8]. There are some studies discussed technical consideration in designing the retention pond for flood control. In planning the retention pond, there are some basic data should be considered in planning the retention pond which is frequency and volume of rainfall, the extent of basin area, average slope and elevation, heterogeneity in hillslope and drainage network [4]. In as much, the technical calculations must be done prior to plan the retention pond at reclaimed lowland area such as calculating the trend for rainfall data and forecasting the highest annual water discharge [3]. The hydrological and hydraulics analysis should be done in the analysis prior to planning the pond. The hydrological analysis is closely related to the pattern of the drainage channel, soil permeability, and rainfall water discharge. The hydraulic analysis is related to the design of the pond, water channel and other water bodies. In the end, the connectivity between the ponds to other water bodies should be connected so that the dynamics and water catchment process run well [9].

All these studies merely discuss the technical aspect of designing the retention pond. The studies that investigated how people use the retention pond is still limited to the awareness of residents on aware of the importance of good sewage system, including retention pond availability [5]. The social aspect of the use of retention pond as recreational place are rarely to be discussed.

\section{B. Social Aspects of Housing Structure}

The social aspect is important in designing the living environment because the elements and people are spatially structured through separation in and by space in the form of culture, social values, perception and preferences [10]. The culture and social value determine the initial setting of the environment; perception determines the decision to modify the current setting and preferences helps to define the expectation and priorities for appropriate new design [10], [11], [12], [13].

To explore the use of retention pond as a recreational area where the residents met one another, this paper relates this function with social aspect on housing structure. Firstly, there is a relation between housing structure and social contact among residents of apartment buildings. The configuration of housing determines the high level of use the communal space [14]. The layout supports positive interaction among residents of housing areas well the quality of communal space. The cluster type of housing layout and U-shape flat blocks creates communal space that makes interaction among residents is possible. Cluster layout also increase visibility amongst the residents to see the neighbour activities and increase social awareness among them [14], [15]. The study on grid layout shows the inconclusive result on layout influences to promote social interaction as well as social gathering activities among the resident. On the contrary, the cul-de -ac layout promotes social interaction and lower social crime [16].

Some studies have shown that the structure of housing layout has an influence on the interaction among the residents, create a space for accommodating residents' social activity and support the quality of life in the neighbourhood. An outdoor space in a certain housing area can be perceived as public space or communal space where the residents can create opportunities for informal interpersonal interaction, consciously and unconsciously. In this situation, space can promote local participation, neighbourhood attachment, and stronger social control among the residents. Hence, the retention pond, as well as the space around it, is a kind of public space that potentially creates a sense of community among the residents. [17]. The use and design of public space at housing area contribute to resident mental health. A study in low rent housing in Tianjin China mentions the need for public space or communal space to increase user satisfaction. As the houses have minimum space, the public space complements the insufficiency space, particularly for communal spaces. The outdoor space is used as an extension of service and public zone of the house. Thus, it enhances socialization and increases residents' happiness [18]. Furthermore, happiness and socialization enhance the resident's mental health. The public space availability as well as the streetscape and greenery in living environment increase socialization and happiness that leads to the support to residents' mental health, reduce stress, stimulate physical activity and facilitate social cohesion [19], [20].

Public space at housing area also contributes to resident's satisfaction. The satisfaction happens when combination among the housing service, location of house and relationship with the neighbour is well functioned [21]. In another word, the public space creates a sense of community. This sense depends on how residents perceive the quality of public open space in their living environment. The quality of public space influences the solidarity and concern among the residents of the housing area. Therefore, residents' participatory in managing the better quality of the public open space and social interaction is important to the resident's satisfaction with their living place [17].

From these reviews, it is clearly stated that the public space in a living environment gives positive impacts on residence life. It enhances the sense of community, increases mental health and satisfaction. The key factors of these are the quality of the public space, especially its design [20]. In as much, the users participatory is important in managing the use and maintenance of the public space [17]. Having these studies, it is a need to explore how to design the space around the retention pond based on residents perception of its function.

\section{MATERIAL AND METHOD}

The paper is aimed to investigate the use of retention pond as attracting attributes of housing product. To achieve this aim, the paper investigated how people perceive the 
significance of the availability of retention pond in their living environment through three variables; function, size and street furniture provided. To collect the data, there are 50 questions on questionnaire sheet. The data from questionnaires were analysed using descriptive statistic and factor analysis. The descriptive statistic was used to gain the current perception of the three variables. The factor analysis was done to get the residents preference on attributes of retention pond area derived from the three variables. A number of 369 respondents had participated in the survey. The respondents were the residents of housing complex which is located in reclaimed lowland area in Palembang. The demography profile of the respondents is shown in Table 1.

TABLE I

DEMOGRAPHY PROFILE

\begin{tabular}{|c|c|c|}
\hline Demography aspects & \multicolumn{2}{|c|}{ Percentage $n=369$} \\
\hline \multirow{2}{*}{ Sex } & Male & 51 \\
\hline & Female & 49 \\
\hline \multirow{5}{*}{ Age } & $<21$ years old & 12 \\
\hline & $21-30$ yrs old & 25 \\
\hline & $31-40$ yrs old & 25 \\
\hline & $41-50$ yrs old & 19 \\
\hline & $>50$ yrs old & 19 \\
\hline \multirow{4}{*}{ Occupation } & Private sector & 23 \\
\hline & Officer & 28 \\
\hline & Worker & 5 \\
\hline & Student and others & 44 \\
\hline \multirow{4}{*}{ Length of stay } & $<5 \mathrm{yrs}$ & 28 \\
\hline & $5-10$ yrs & 37 \\
\hline & $11-20 \mathrm{yrs}$ & 24 \\
\hline & $>20 \mathrm{yrs}$ & 12 \\
\hline \multirow{4}{*}{ Frequency of Flood } & Once a year & 20 \\
\hline & 2-3 times in a year & 29 \\
\hline & Every 5 years & 14 \\
\hline & Every heavy rain & 37 \\
\hline \multirow{3}{*}{ Retention pond } & available & 57 \\
\hline & unavailable & 33 \\
\hline & available in past & 10 \\
\hline
\end{tabular}

To complement the statistic analysis, an in-depth interview was conducted with five key residents of the housing area. The interviewees were the residents of lowland housing complex who have stayed for more than 5 years.

As shown in Table 1, the respondents are dominated by adults with the age range from 21 to 50 years old (88\%). Most of them are working as officers $(28 \%)$ and private sector $(23 \%)$. The respondents have a relatively long length of stay. There are $71 \%$ of them have stayed for more than five years. From 369 respondents, $29 \%$ of them experienced the regular flood 2 to 3 times in a year, and $37 \%$ of them experienced the flood in every heavy rain. There is $33 \%$ of the respondents' mentioned that there is no retention pond in their housing area, while $10 \%$ of them mentioned that there was a retention pond. The demography profile shows that the respondents are representative for the aim of the research.

\section{RESULT AND DISCUSSION}

The descriptive statistic is used to gain the current perception of the three variables; function, size and street furniture. The questions for this purpose are two types, single and multi answered. The single answered question asked respondents perception on the need to provide retention pond at reclaimed lowland housing area and their frequency of use. The multi answered one questioned the possibility of sub-variables in attracting the residents to use the retention pond and its surrounding. The sub-variables are activities, time usage, and completeness. The results are shown in following tables.

TABLE II

PERCEPTION ON FUNCTION

\begin{tabular}{|c|c|c|}
\hline Variables & \multicolumn{2}{|c|}{ Percentage $n=369$} \\
\hline \multicolumn{3}{|l|}{ Function } \\
\hline \multirow{2}{*}{$\begin{array}{l}\text { Need to have retention } \\
\text { pond }\end{array}$} & Necessary & 96 \\
\hline & No necessary & 4 \\
\hline \multirow{3}{*}{ Frequency of use } & Never & 25 \\
\hline & Rare (approx 1-3 times) & 59 \\
\hline & Every week & 12 \\
\hline \multirow{8}{*}{ Activities } & Fishing & 44 \\
\hline & Gathering & 45 \\
\hline & Selling & 30 \\
\hline & No idea & 37 \\
\hline & Sport/exercise & 6 \\
\hline & Taking a walk & 27 \\
\hline & Playing & 2 \\
\hline & Other & 5 \\
\hline \multirow{4}{*}{ Time usage } & Morning & 31 \\
\hline & Midday & 3 \\
\hline & Afternoon & 89 \\
\hline & Night & 2 \\
\hline
\end{tabular}

Results in Table 2 shows that $96 \%$ of respondents agree with the need of retention pond in reclaimed lowland housing area. However, only $12 \%$ of the respondents visit the area of the retention pond every week. This number is in accordance with $43 \%$ of respondents mentions that their housing area has no retention pond. Related to function, results show that fishing and gathering are the most activities held at retention pond area with the percentage of response are $44 \%$ and $45 \%$ respectively. Most activities are done in the afternoon (89\%) and/or morning (31\%). However, $37 \%$ of respondent have no idea on what kind of activities can be held at retention pond area. This number implies that this group of respondent was only aware of the technical function of retention pond area.

Related to the size and street furniture, respondents were asked about their opinion on the completeness of attributes of a retention pond area. Table 3 shows the sitable area is the highest percentage $(56 \%)$, followed by the gazebo, static fitness equipment, and grass field respectively. These numbers imply attributes of the public space that support that social and recreational activity. In addition, there is only $1 \%$ of respondent perceive concrete pavement as a considerable attribute. There are $24 \%$ of respondent affirm the attribute of the tree as considerable one. It is in line with $37 \%$ of respondents that considers grass field as an important attribute. It is clearly shown that the size of retention pond area is similar to the scale of a field. This also implies that greenery attributes are perceived as elements that should be provided at retention pond area.

The factor analysis is done to understand the residents' preference on attributes of retention pond derived from the three variables (function, size and street furniture). There are 18 attributes were coded. The codes are shown in Table 4. 
TABLE III

PERCEPTION ON SIZE AND STREET FuRNITURE

\begin{tabular}{|l|l|l|}
\hline \multicolumn{2}{|c|}{ Variables } & \multicolumn{2}{c|}{ Percentage n=369 } \\
\hline Size and street furniture & \multicolumn{2}{|c|}{} \\
\hline \multirow{5}{*}{ Completeness } & Grass field & 37 \\
\cline { 2 - 3 } & Jogging track & 18 \\
\cline { 2 - 3 } & Sittable area & 56 \\
\cline { 2 - 3 } & Garden lamp & 30 \\
\cline { 2 - 3 } & Static fitness equipment & 38 \\
\cline { 2 - 3 } & Gazebo & 39 \\
\cline { 2 - 3 } & Garden/flower & 21 \\
\cline { 2 - 3 } & Pavement/concrete path & 1 \\
\cline { 2 - 3 } & Trees & 24 \\
\hline
\end{tabular}

TABLE IV

ATTRIBUTES CODING

\begin{tabular}{|l|l|}
\hline Code & \multicolumn{1}{|c|}{ Attribute of retention pond area } \\
\hline Var01 & Distance from residential street \\
\hline Var02 & Pathway to the pond area \\
\hline Var03 & Flowers and trees \\
\hline Var04 & Prefer gazebo than bench \\
\hline Var05 & More than one gazebo \\
\hline Var06 & Jogging track \\
\hline Var07 & Concrete pavement or field \\
\hline Var08 & Static fitness equipment \\
\hline Var09 & Vendor \\
\hline Var10 & More grass than concrete \\
\hline Var11 & Clear visibility in the night \\
\hline Var12 & Safety ring fence around the pond \\
\hline Var13 & Ring fence around the area of the pond \\
\hline Var14 & Embankment around the pond \\
\hline Var15 & Playing ground \\
\hline Var16 & Rectangular form \\
\hline Var17 & Parking lot \\
\hline Var18 & Dust bin \\
\hline
\end{tabular}

The data from the questionnaire were analysed by analysis factor. The calculation was done by PASW 18. To gain sample adequacy, Kaiser-Meyer-Olkin (KMO) and Bartlett's Test was done to ensure the data were adequate and reliable. The result of KMO and Bartlett's Test are shown in Table 5 as follows.

TABLE V

KMO AND BARTLETT'S TEST

\begin{tabular}{|c|c|c|}
\hline \multicolumn{3}{|c|}{ Value } \\
\hline \multicolumn{2}{|c|}{$\begin{array}{l}\text { Kaiser-Meyer-Olkin Measure of Sampling } \\
\text { Adequacy }\end{array}$} & .701 \\
\hline \multirow{3}{*}{$\begin{array}{l}\text { Bartlett's Test of } \\
\text { Sphericity }\end{array}$} & Approx. Chi-Square & 1911.531 \\
\hline & Df & 153 \\
\hline & Sig. & .000 \\
\hline
\end{tabular}

KMO value was ranged from 0 to 1 . The sample is adequate when the KMO value is greater than 0.5. The sample is reliable when the Sig. value of Barlet Test value is smaller than 0.1[22]. Table 5 shows that the value of KMO was 0,701 and sig value of Barlett Test is 0.00 . These number shows that sampling is adequate and factor analysis is appropriate.

Responses on 18 attributes were extracted using Principal Component Analysis (PCA). The results of PCA has seven iterations and has extracted the attributes into six groups. Each group represents one component of respondent's preferences. The results on extraction are shown in Table 6 . In order to have a good paper presentation, only data with value more than 0.5 are presented in Table 6 .
TABLE VI

ROTATED COMPONENT MATRIX ${ }^{\mathrm{A}}$

\begin{tabular}{|l|c|c|c|c|c|c|}
\hline \multirow{2}{*}{ Variable } & \multicolumn{5}{|c|}{ Component } \\
\hline & $\mathbf{1}$ & $\mathbf{2}$ & $\mathbf{3}$ & $\mathbf{4}$ & $\mathbf{5}$ & $\mathbf{6}$ \\
\hline Var13 & .907 & & & & & \\
\hline Var12 & .905 & & & & & \\
\hline Var14 & .736 & & & & & \\
\hline Var04 & & .891 & & & & \\
\hline Var05 & & .860 & & & & \\
\hline Var09 & & .564 & & & & \\
\hline Var11 & & & .685 & & & \\
\hline Var18 & & & .647 & & & \\
\hline Var10 & & & .562 & & & \\
\hline Var06 & & & .519 & & & \\
\hline Var17 & & & & .747 & & \\
\hline Var15 & & & & .653 & & \\
\hline Var08 & & & & .645 & & \\
\hline Var16 & & & & .551 & & \\
\hline Var02 & & & & & .819 & \\
\hline Var01 & & & & & .777 & \\
\hline Var03 & & & & & & .654 \\
\hline Var07 & \multicolumn{7}{|l|}{ Extraction Method: Principal Component Analysis. } \\
\hline \multicolumn{7}{|l|}{ Rotation Method: Varimax with Kaiser Normalization. } \\
\hline
\end{tabular}

Table 6 shows that fence attributes in the first group (var13, var12, and var14) are the most preferred by respondents. It implies that safety from the risk of falling into the pond and risk of social crime become the first consideration for respondents. The second group of attributes is var04, var05, and var09. It implies that sitting area, complemented by the vendor, is the second consideration. The third group is the street furniture (var11, var18, var10, and var06). It indicates that lamp, dust bin, grass, and jogging track are the next preferable furniture. Parking lot (var17), playing ground (var15), fitness equipment (var08), rectangular form of space (var16) are grouped in fourth consideration. Pathway (var02) and distance from the residential street (var01) are in the fifth group, followed by flowers (var03) and concrete pavement or field (var07) in the last group.

To complete these results, the interview has questioned on how interviewees prefer the design of retention pond area. Similar to the target of the questionnaire, the interview also targeted the residents whose house were located at reclaimed lowland area in Palembang. There were the residents of Sangkuriang Indah, Griya Maharani and Catelya (Sako District); Bukit Sejahtera (Bukit Lama District) and Kedamaian Permai 2 (Bukit Sangkal District). In order to get a deep interview result, the interviewees should have a length of stay more than 15 years. The interviewer conducted the interview in morning and afternoon as these are the proper time for residents. In fact, most of the interviews were conducted at afternoon. The average time for one interview was 30 to 45 minutes.

The following discussion elaborates the transcript of the interview. For the purpose of paper presentation, only the representative transcripts were shown. The discussion is started from the three general questions; (1) buying experience, (2) understanding on lowland and retention pond function and (3) resident's opinion on the design of the retention pond as well as other water catchment area at their neighborhood. Then, the content of transcripts was analyzed 
according to the three research variables. The results from the general question and the responses on three research variables were complementing each other as evidence from the resident's point of view.

In order to gain residents' experience when bought the house, the interviewer asked the interviewees on two aspects; the resident's awareness on the character of lowland area as the location of the house and their experience when the flood happened at housing area. For the first aspect, the interviewees found no indication of the regular flood in their housing area. Therefore, they felt the location was free from the risk of flood, as reflects on the following transcripts.

"When I decided to buy this house, there was no indication of the flood in this area. I found it as dry land area. The flood happens in the late five years. I do not know for sure (the reason), perhaps water cannot flow to the water catchment area any longer" (a 40 years old man, a banker, lived at Sangkuriang Indah)

Another resident of Sangkuriang Indah who was 50 years old mentioned that he did not take attention on the land occupation trend in his decision to buy. His statements are shown as follows.

"When bought this house, Yes I consider that this area will be developed in the future. Vacant land will be reclaimed. Many new housing will be built. However, I did not consider the effect of these land occupation on the flood. I did not think about it when I bought my house, unpredictable."

The different statement was expressed by a 60 years old man, lived at Griya Maharani. He mentioned that he had already realized the nature of reclaimed land at his housing area. Therefore, he understands the causing of the flood, as reflects in the following expressions:

\begin{abstract}
"Some part of this area was dry land; the other part was reclaimed lowland. When there was a flood, it only reached the main road area. The houses were not affected by the flood. In as much, this housing was the first one in this area. As the vacant lands were developed, there are many housing areas now. Perhaps, it causes the flood. Actually, I am not surprised by the flood phenomenon in this area. It is normal since this area has a combination of the dry land and reclaimed lowland."
\end{abstract}

The same thought also reflects from a transcript of a 60 years old man who lived at Bukit Sejahtera. He conveyed his understanding of the cause of the flood, as follows.

"I heard from senior residents who lived near this area. He was one of the craftsmen who built the complex. He said, the volume of land to reclaim the marsh was approximately two meter in height. No wonder, the flood is spreading now".

Regarding the flood, a resident lived at Bukit Lama express her experience as follows.
We are lived on the front side of this complex; there was no flood. Flood was only on the back side since it is relatively lower than the front side. However, the situation becomes worst since the marsh (a natural one) was reclaimed. The flood reaches our houses. It could be caused by the reclamation. (52 years old, civil servant lived at Bukit Sejahtera)

Another complaint on flood also expressed by a resident of Kedamaian Permai 2. She experiences the flood since the vacant land was developed, as reflects on her statement.

Actually, this housing area has a retention pond already. Everything was fine, no flood at all. The flood has occurred since the development of Kesuma Bangsa School. The street is always full of water when heavy rain. The water flows to our housing area.

From the mentioned expression, the study concludes that the residents have two conditions prior to the decision to buy the house which is aware and not aware of the character of lowland area. For the first group of resident, they understand the risk and can predict the flood. However, the current flood is their prediction. The other group has different awareness. They bought the house without considering the risk of flood in the future. Their experience on the flood had increased their understanding of the technical function of retention pond or water catchment area for a reclaimed lowland housing area.

Regarding the residents' understanding of lowland and retention pond, the interviewer also asked the interviewees about the current usage of the retention pond area. Some expressions are stated as follows.

"I am not sure how we can use the retention pond, only fishing. It is different from the Kambang Iwak (a famous communal space in Palembang that is also a retention pond). People of Palembang can use it for recreation. We cannot conduct a leisure activity at the retention pond in this housing complex. There is only a few people use it, for fishing and jogging. We are afraid of falling into the pond. I almost never use that area, only fishing, only a few times" (A 48 years old man, lived at Griya Maharani)

"The pond was there, at the back side. I never go there, almost never. If I want to take a walk with my children, I only go to this front side" (A 35 years old lady, lived at Sangkuring Indah)

"We conduct our social gathering at house or mosque. We seldom use retention pond area for it. Especially for our children, the pond is dangerous. Even though the area was good for outdoor activity, I do not allow my children are playing near the pond. I am afraid they will fall into the pond" (A 45 years old lady, lived at Griya Maharani)

From the transcripts, the study concludes that residents have understood on the safety issue on the pond area. They feel reluctant to use the area as the designs do not provide 
appropriate elements or furniture that minimizes the risk of falling into the pond. Related to this issue, a selected expression represents the resident's opinion on the ideal design of the pond area. Her statement is shown as follows.

"If the pond is designed similar to Kambang Iwak, perhaps the residents will use it more. Not only the pond. Kambang Iwak has many things for people to do the activity. It has jogging track, sitting area. The pond (area) can be good for positive behavior of the residents. And it should not accommodate negative behavior, such as dating, etc. No, definitely no. The place can be used for exercise, aerobic, as well as national independence celebration. As you can see, the pond is not well designed now" (40 years old lady, lived at Griya Maharani)

In conducting a content analysis, the questions of the interview were derived from the three variables; function, size, and furniture. To know the function, interviewees were asked about the current activities held in the retention pond area. They also were asked their experiences on the dimension of space used and the furniture used for those activities. Related to the function, the interviewees were also asked on their opinion on the technically well functioned of the retention pond to handling the overflow of discharge rain runoff water.

They were also interviewed on their opinions on the potential activities that can be held on the retention pond area and the extent of the comfort in using it. Further, their opinion on the proper size as well as furniture types was also elaborated. Besides answering the questions delivered by the interviewer, the interviewee also expressed their demand for the design elements at retention area. Their transcripts were noted to compliment the design demand on the three variables; function, size, and furniture.

Table 7 shows the derivation of research variable in the question of the interview. The function variable underlines the current use of the retention pond. The size variable derives the dimension from the number of the pond provided in the housing area and how people use the area. The number of the pond relates to the size of the housing area. The usage of the pond shows the space needed to accommodate the activities The question on the design element as well as safety issue implies the variable of furniture. The question and variables are shown in Table 7 , while the example of content analysis is shown in Table 8.

The transcripts from the interview were coded. The coding was based on the variables. For variable function, the transcript has elaborated the expression that showed the activities that potentially occurred and had not been accommodated yet. The logic is these expressions imply that there were some existed activities held at other places. Therefore, in this study, these expressions were coded as demanded function. Beside the demanded function, the expressions that mentioned the activities held at the pond area were also noted as another sub-variable of the function. It was coded as current use function.

The next variable coded was size. It was easy to gain the number of ponds based on the transcript. On the contrary, most of the interviewee could not answer the question in the exact dimension of pond area. They mentioned it in approximate dimension or number. The last variable coded was the street furniture. It addressed to the words in transcripts that expressed the tools or facilities provided or had not provided at retention pond area. It could be as an opinion as well as existing data. Each transcript was analyzed by noting the word expressed to gain the underlined variable or sub-variable. Table 9 shows how the variables were coded from the transcripts.

TABLE VII

QUESTIONS OF INTERVIEW

\begin{tabular}{|c|l|}
\hline Variables & \multicolumn{1}{c|}{ Question(s) } \\
\hline Function & $\begin{array}{l}\text { What are the functions of the retention pond } \\
\text { as well as its surrounding area that } \\
\text { contribute to your life in this residential } \\
\text { area? } \\
\text { Do you think it is work for handling the } \\
\text { overflow of rain runoff water? }\end{array}$ \\
\hline Size & $\begin{array}{l}\text { How many retention ponds are in this area? } \\
\text { How do people conduct their activity? }\end{array}$ \\
\hline \multirow{2}{*}{ Furniture } & $\begin{array}{l}\text { How do they do their activities, do they } \\
\text { need a bench or other street furniture for } \\
\text { this activity? } \\
\text { Is it safe for people to conduct their } \\
\text { activities around the pond? }\end{array}$ \\
\hline
\end{tabular}

TABLE VIII

EXAMPLE OF CONTENT ANALYSIS

\begin{tabular}{|l|l|}
\hline \multicolumn{1}{|c|}{ Transcripts content } & $\begin{array}{l}\text { Code } \\
\text { analyzed }\end{array}$ \\
\hline $\begin{array}{l}\text { Actually, it can be the place for jogging and } \\
\text { family recreation or a place to celebrating } \\
\text { the National Independence Day. However, it } \\
\text { is not well designed... (a 50 yrs old banker, } \\
\text { living at Sangkuriang) }\end{array}$ & $\begin{array}{l}\text { Function } \\
\text { (demand) }\end{array}$ \\
\hline $\begin{array}{l}\text { This housing has a pond at the front, and } \\
\text { another one at the backside, perhaps it is for } \\
\text { a retention pond. I see so many people come } \\
\text { for fishing. (a 45 yrs old man, living at }\end{array}$ & $\begin{array}{l}\text { Size and } \\
\text { Function } \\
\text { Kedamaian Permai 2) }\end{array}$ \\
\hline $\begin{array}{l}\text { If the pond is designed similar to Kambang } \\
\text { Iwak, perhaps the residents will use it more. } \\
\text { Not only the pond...It has jogging track, } \\
\text { sitting area. The pond (area) can be good for } \\
\text { positive behavior of the residents. And it } \\
\text { should not accommodate negative behavior, } \\
\text { such as dating, etc. No, definitely no. The } \\
\text { place can be used for exercise, aerobic, as } \\
\text { well as national independence celebration }\end{array}$ & $\begin{array}{l}\text { Furniture } \\
\text { (opinion) }\end{array}$ \\
\hline
\end{tabular}

The results shown in Table 6 implies that safety becomes the first consideration in conducting an activity within residential public space. This is in line with the content of the transcript in Table 9. The results also show that the respondents realize the advantage of public open space to enhance social interaction, as seen by their preference on place ability to accommodate gathering and provide a sitting area. However, the issue of safety is more determined than leisure and social interaction issues. The attributes that are related to street furniture and design element and also support social activity are less considered than the safety furniture. 
TABLE IX

RESULT OF TRANSCRIPT CODING

\begin{tabular}{|c|c|}
\hline Code & Attribute of retention pond area \\
\hline Function & $\begin{array}{l}\text { Place for jogging and family recreation (a } 50 \\
\text { yrs old banker, Sangkuriang Indah) } \\
\text { Place for fishing (a } 45 \text { yrs old man, Kedamaian } \\
\text { Permai } 2 \\
\text { Potential playing ground for children (a } 40 \text { yrs } \\
\text { old lady, teacher, Catelya) } \\
\text { Place for social gathering ( } 43 \text { yrs old lady and } \\
48 \text { yrs old man, Sangkuriang) }\end{array}$ \\
\hline $\begin{array}{l}\text { Size and } \\
\text { furniture }\end{array}$ & $\begin{array}{l}\text { Only one gazebo (a } 50 \text { yrs old banker, } \\
\text { Sangkuriang Indah) } \\
\text { Lamp, to avoid criminal action ( } 40 \text { yrs old } \\
\text { man, Catelya) } \\
\text { Jogging track, near place for exercise ( } 45 \text { yrs } \\
\text { old man, Kedamaian Permai } 2 \text { ) } \\
\text { Fence, to protect the children from falling into } \\
\text { the pond...potential for playing without } \\
\text { parents watch.( } 38 \text { yrs old housewife, } \\
\text { Sangkuriang Indah) } \\
\text { Have distance from the communal area, to } \\
\text { avoid risk of falling into the pond ( } 48 \text { yrs old } \\
\text { man, Sangkuriang Indah) }\end{array}$ \\
\hline $\begin{array}{l}\text { Points of } \\
\text { design } \\
\text { demand }\end{array}$ & $\begin{array}{l}\text { Safety from falling risk } \\
\text { Clear and controlled area from insecure } \\
\text { activities } \\
\text { Playing ground, jogging track, open area or } \\
\text { field. }\end{array}$ \\
\hline
\end{tabular}

\section{CONCLUSION}

The conclusion of this research is the residents of the reclaimed lowland housing area are aware of the benefit of having public space around the retention pond. They realize the need for public space for social interaction. However, there is design requirement that must be fulfilled before using the public space for social interaction. It concludes that the retention pond area is not the main attractive attribute of housing product even though the drainage system is considered as important one and the open area is necessary for residents' social activity. The paper concludes that in planning the housing site, particularly the retention pond area, the street furniture that fulfills the safety standards must become the first design consideration before providing other landscape furniture that supports the residents' social activities. Therefore, the retention pond area can be an attractive element for the housing site.

\section{ACKNOWLEDGMENT}

This paper is a part of research publication on lowland development study supported by Unggulan Kompetitif Universitas Sriwijaya Year 2016. Authors would like to thank Lembaga Penelitian dan Pengabdian Masyarakat Universitas Sriwijaya for the financial support

\section{REFERENCES}

[1] Nugroho, S, "Urban Morphology at Lowland Environment in Palembang" in Proceeding of the 13th International Conference on Sustainable Environment and Architecture, 2012.
[2] Edwin, Saidi A, Aprisal, Yulnafatmawita, Carolita I. "Spatial and Temporal Analysis of Land Use Change for 11 years (2004-2014) in Sub-Watershed Sumpur Singkarak", International Journal on Advanced Science Engineering Information Technology, Vol.5 (5),pp 326-329, 2015

[3] Mah, D.Y.S and Ho, T.Y, "Alternative Use of Roundabout as Storm Water Detention Pond”, Journal of Civil Engineering, Science and Technology. Vol.8 (1), pp. 15-24, 2017

[4] Chapman, K, “ A Location Allocation Model for Retention Basin Placement on Vacant Land in Detroit, MI" Master Thesis, Western Michigan University,

[5] Ravazzani G, Gianoli P, Meussi S., Mancini M. "Assesing Downstream Impacts on Detention Basin in Urbanized River Basin Using a Distributed Hydrological Model". Water Resources Management, Vol.28, pp.1033-1044. 2014

[6] Anwar, W.F.F dan Nugroho, S, Pengendalian Pembangunan Lahan Basah Berbasi Preferensi Penghuni Terhadap Kualitas Infrastruktur Pada Lingkungan Perumahan Rawa Urug. Penelitian Unggulan Kompetitif, UNSRI, 2015.

[7] Direktorat Jenderal Cipta Karya Departemen Pekerjaan Umum, Tata Cara Pembuatan Kolam Retensi Dan Polder Dengan Saluran-Saluran Utama. Jakarta, 2010.

[8] Costa CS, et.al, "Water as an Element of Urban Design: Drawing Lessons from Four European Case Studies". Sustainable Water Use and Management, Springer, pp 17-43, 2015

[9] Steel, M.K., Hefferman, J.B., "Morphological Characteristics of Urban Water Bodies; Mechanism of Change and Implications for Ecosystem Function", Ecologial Application, Vol.24(5), pp.10701084, 2014.

[10] Rapoport, A. Human Aspect of Urban Form, Pergamon Press, 1977

[11] Sitompul, R. Brouwer, R, Sopaheluwakan, J, van Beukering, P, "Farm Household Preferences and Evaluation of Land Use Change Policies for Agro-Forestry Plantations in Central Kalimantan, Indonesia : a Choice Experiment", International Journal on Advanced Science Engineering Information Technology, Vol.6 (2),pp 210-215, 2016

[12] Loures, L., Panagopoulos, T., \& Burley, J. B, Assessing user preferences on post-industrial redevelopment", Environment and Planning B: Planning and Design, Vol. 43(5), pp.871-892, 2016

[13] Sahar S. Abdalla, S.S, Elariane, S,A, El Defrawi, S.H, "DecisionMaking Tool for Participatory Urban Planning and Development: Residents' Preferences of Their Built Environment", Journal of Urban Planning and Development, Vol. 142 (1), 2016

[14] Glaeser, E.L. and Sacerdote, B, "The Social Consequences of Housing', National Bureau of Economic Research. (w8034), 2000.

[15] Aziz, A.A., Ahmad, A.S., "Flat Layout and Children Outdoor Activities", Asian Journal of Environment Behaviour Studies, Vol 2 (3), pp.57-66, 2017.

[16] Cozens, P.M and Hillier, D. "The Shape of Things to Come: New Urbanism, the Grid and Cul-De-Sac", International Planning Studies, Vol.13(1), pp.51-73, 2008.

[17] Zhu, Y,'Toward Community Engagement: can the Built Environment Help? Grassroots Participation and Communal Space in Chinese Urban Communities", Habitat International, Vol.1(46) pp. 44-53, 2015.

[18] Li, X., Shen, Z., \& Kobayashi, F, "Planning Review on Residential Environment of Low Rent Housing: A Method To Solve Low-Rent Housing Space Insufficiency In Tianjin, China”, International Review for Spatial Planning and Sustainable Development, Vol. 3(3) pp. 50-62, 2015.

[19] Francis, J., Giles-Corti, B., Wood, L., \& Knuiman, M, "Creating Sense Of Community: The Role Of Public Space", Journal of Environmental Psychology, Vol .32(4) pp. 401-409, 2012

[20] De Vries, S., van Dillen, S. M., Groenewegen, P. P., \& Spreeuwenberg, P, "Streetscape Greenery And Health: Stress, Social Cohesion And Physical Activity As Mediators", Social Science \& Medicine, Vol. 94 pp. 26-33, 2013.

[21] Mohit, M. A., \& Azim, M, "Assessment of residential satisfaction with public housing in Hulhumale', Maldives", Procedia-Social and Behavioral Sciences, Vol. 50 pp. 756-770, 2012.

[22] Field, A, Discovering statistic using SPSS, Vol. 2, Sage pub, 2005. 